岡山医誌（1994） 106，1025－1033

\title{
気管支喘息における病態に基づく新しい 病型分類に関する研究
}

岡山大学医学部第二内科学教室（指導：木村郁郎教授）

木 村 和 陽

(平成 6 年 5 月 17 日受稿)

\begin{abstract}
Key words : asthma classification, lymphocyte blastogenesis, Candida, house dust $\cdot$ mite, IgE RAST
\end{abstract}

緒言

近年気管支喘息の概念は大きく変化し，従来 の気道平滑筋緊張異常説のみならず慢性のアレ ルギー性炎症説りに基づいた定義がなされている。 またその喘息発作は即時型気道反応 (以下 IAR) と途発型気道反応（以下 LAR），さらには遅延 型気道反応 (以下 DeAR) に代表される気道反 応を基盤にすることが判明し，そのうちIARは 抗原特異的 IgE 抗体々肥满細胞 - 好塩基球系を 介した I 型アレルギー反応の関与する小児のア トピ一型喘息の基本病態と考えられる。一方成 人喘息のそれはさらに複雑で LAR の関与が想 定され，好酸球，好中球さらには，これらを統 御するリンパ球の関与した, いわゆる細胞反応 型アレルギー2334)として理解されつつある.

一方気管支喘息の病型分類は幾多の変遷を経 てこれまでに Swineford ${ }^{5)}$, Rackemann ${ }^{6)}$, Scadding ${ }^{7)}$, Rose $^{8)}$, Pepys ${ }^{9)}$, Thurlbeck ${ }^{10)} ら に$ よって複雑な病態に対する分類が試みられてい る. なかでも Swinefordによるアトピー型, 感 染型, 及びこれらの混合型, もしくは Rackemann らによる外因型, 内因型とに分類する方法が沉 用されてきた。そして小児喘息はさておき，前 述の成人喘息病態が次第に解明されるに至り, それを表現するには従来の分類は必ずしも適切 でなく，新なな喘息病型分類が必要とされてい る.

そこで今回著者は代表的な抗原である house dust (以下 HD) - mite と Candidaによる抗原 吸入誘発試験（bronchial provocation test, 以 下 BPT)で発現する気道反応様式を参考にして, 抗原特異的 IgE 抗体 (以下 IgE RAST) と抗 原特異的なリンバ球幼若化反応 (lymphocyte blastogenesis 以下 Ly-BL) の態度を基準にし た新しい病型分類を考案し，またその分類に従 つた臨床病型の特徽についても検討した。

\section{対象と方法}

\section{1. 对 象}

岡山大学医学部第 2 内科外来通院中または入 院中の気管支喘息患者 49 例（17～77歳，平均 46 歳, 男性25例，女性24例）を対象とした。臨床 的検索については IgE RAST 及び Ly-BLは全 症例に施行し, 一般に病歴, 臨床症状, 皮内反 応試験, 血清絵 IgE (RIST) 值, 気道過敏性試 験，BPT について実施した。なお BPT 施行 例は HD 抗原, Candida 抗原ともに38例であっ た.

2. 方法

1) 抗原吸入誘発試験 (BPT)

日本アレルギ一学会による吸入試験の標準法 ${ }^{11}$ に準じて Candida 抗原または HD 抗原（鳥居 製薬）を用いて BPT を行い，対照として吸入

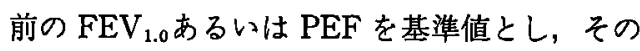
$20 \%$ 以上低下した場合を気道反応陽性と判定し た.さらにその発現時間が吸入から 1 時間以内 をIAR, 3 時間以降にピークを示寸場合を LAR に分類した。なお mite 抗原吸入に際して時に 大発作が誘発されることがあり, 安全性に問題 
があることより今回は HD 抗原を使用した.

2 ) 抗原特異的 IgE 抗体 (IgE RAST)

mite 抗原及び Candida 抗原に対する血清中 抗原特異的 $\operatorname{IgE}$ 抗体值は CAP (Capsulated hydrophic carrior polymer system) 法 (Pharmacia 社)を用いて測定した。 なお mite, Candida ともに score 2 以上を陽性とした.

3) 抗原特異的リンパ球幼若化反応 (Ly-BL)

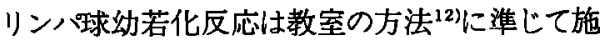
行した。すなわち患者の肘静脈からへパリン加 で10 $\mathrm{ml}$ の末梢血を採取し，比重遠沈法により 単核球層を分離後, $10 \%$ FCS 加 RPMI 1640 に て $1 \times 10^{6}$ 個 $/ \mathrm{ml}$ の細胞浮遊液に調整した. この 浮遊液を $100 \mu 1$ ずつ96 well flat bottom plate (Costar 社) の各 well に分注した.これに Candida 抗原は $132 \mu \mathrm{g} / \mathrm{ml}$, mite 抗原は $160 \mu \mathrm{g} /$ $\mathrm{ml}$ の濃度になるように添加し, $37^{\circ} \mathrm{C}, 5 \% \mathrm{CO}_{2}$ の条件下で triplicate にて 6 日間培養し，培養 終了 7 時間前に ${ }^{3} \mathrm{H}$-Thymidine (Amersham社) を最終濃度1.0 $\mu \mathrm{Ci} / \mathrm{ml}$ となるように各 well に 加之た。培着終了後 Semi-automatic harvester (Labo science 社) にて細胞を採取し，液体シ ンチレーションカウンターにて測定した放射活 性のうち, 抗原添加群と非添加群の dpm との 比を stimulation index (S. I.) として表示した. なお健常人の Mean+2SD である mite のS. I. 2.1以上, Candida のS. I. 3.0以上を Ly-BL 亢 進（陽性）とした。

推計学的有意差検定には Student's- T test を 用い, $\mathrm{p}<0.05$ を有意差ありとした。

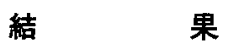

1. IgE RAST 及びリンパ球活性化と気道反応 の関係

1) IAR について

まず HD 抗原による BPT 施行患者38例につ いて IgE RAST とIAR との関連性を検討した ところ, IgE RAST 陽性の19例中 IAR 陽性例 は 9 例 (47\%) と半数以下であり，半数を越之 る陰性を認めた。 IgE RAST 陽性例が必ずしも IAR を発現するとは限らないことが判明した。 しかし逆に IAR の有無により2群に分け IgE RAST を比較検討すると,IAR を発現した群で
は mite の IgE RAST score が有意に高い傾向 が認められた（p<0.01）（Fig. 1).

なお Candida 抗原による BPT 施行患者38 例についても同様に検討したが, IAR と IgE RAST との相関は認められなかった。

次に IAR と Ly-BLの関係を検討したが, mite も Candida も両者間に一定の傾向は認められな かった.

2) LAR について

次に IgE RAST とLAR との関連性を検討し たが, mite, Candida ともに一定の傾向は認め られなかった．そこで mite 抗原特異的 Ly-BL と HD 抗原吸入による LAR との関連性を検討 したところ，S. I. 六進例では LAR 発現例は 14 例中11例 (79\%) と高い一致率であることが判 明した。逆に LAR 非発現群及び発現群の 2 群 に分けて，Ly-BL を比較したところ，LAR 発 現群の S. I. は有意に穴進していた（p<0.01）

(Fig. 2).

Candida 抗原による BPT 施行患者について も同様に検討したころ, Candida のLy-BL え進 例では LAR 発現例が多かった。 一方 LAR 非 発現群及び発現群の 2 群に分けると, LAR 発現 群の Ly-BLの S. I. は有意に高かった $(\mathrm{p}<0.01)$

(Fig. 3).

以上より HD, Candida ともに, LAR とリ ンハ球の活性化とはよく一致する事が判明した。

2. IgE RAST とLy-BL による新たな喘息病 型分類の試み

次に前項の結果を基に気道反応出現態度の特 徵を示す IgE RAST score と Ly-BLの S. I. を 指標として喘息病態の分類をすると, Table 1 の如く 4 群に分類された。 すなわち mite ある いは Candida の特異抗原に対して，A群は IgE RAST 陽性で Ly-BL 陰性，B群は IgE RAST, Ly-BL ともに陽性，C群は IgE RAST 陰性で Ly-BL 陽性，D群は IgE RAST, Ly-BL とも に陰性の各群であった。

3 . 新分類と気道反态の関連

かかる分類法に従って各群における気道反応 の発現頻度を検討してみると IgE RAST の元 進しているA群, B群では Dual も含めた IAR の発現は半数以下 $(42 \%, 39 \%)$ であった。 ま 


\begin{tabular}{|c|c|c|}
\hline & \multicolumn{2}{|c|}{ IAR } \\
\hline & + & - \\
\hline $\begin{array}{c}\text { IgE RAST } \\
{ }^{*} \text { positive } \\
n=19\end{array}$ & $\begin{array}{c}9 \\
(47 \%)\end{array}$ & $\begin{array}{c}10 \\
(53 \%)\end{array}$ \\
\hline $\begin{array}{c}\text { ** negative } \\
n=19\end{array}$ & $\begin{array}{c}1 \\
(5 \%)\end{array}$ & $\begin{array}{c}18 \\
(95 \%)\end{array}$ \\
\hline
\end{tabular}

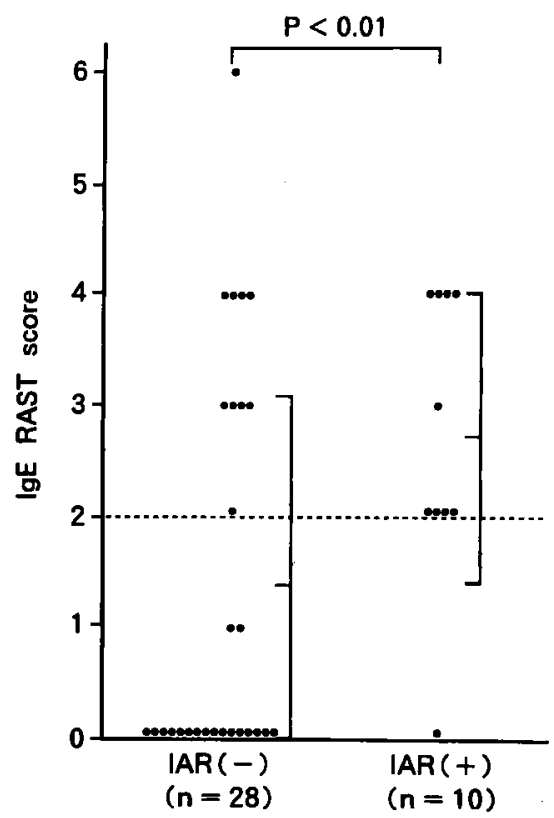

Fig 1 Relation between mite specific IgE antibodies and IAR provoked by inhalation of house dust antigen. Mite specific IgE antibodies are expressed as IgE RAST score. IAR : immediate asthmatic response

\begin{tabular}{c|cc} 
& \multicolumn{2}{|c}{ LAR } \\
\cline { 2 - 3 } & + & - \\
\hline $\begin{array}{c}\text { Ly-BL } \\
\text { positive } \\
n=14\end{array}$ & $\begin{array}{c}11 \\
(79 \%)\end{array}$ & $\begin{array}{c}3 \\
(21 \%)\end{array}$ \\
\hline $\begin{array}{c}* \text { negative } \\
n=24\end{array}$ & 5 & 19 \\
$(21 \%)$ & $(79 \%)$ \\
\hline $\begin{array}{c}* \text { positive s.I. } \\
* * \text { negative s.I. } 2.1\end{array}$ &
\end{tabular}

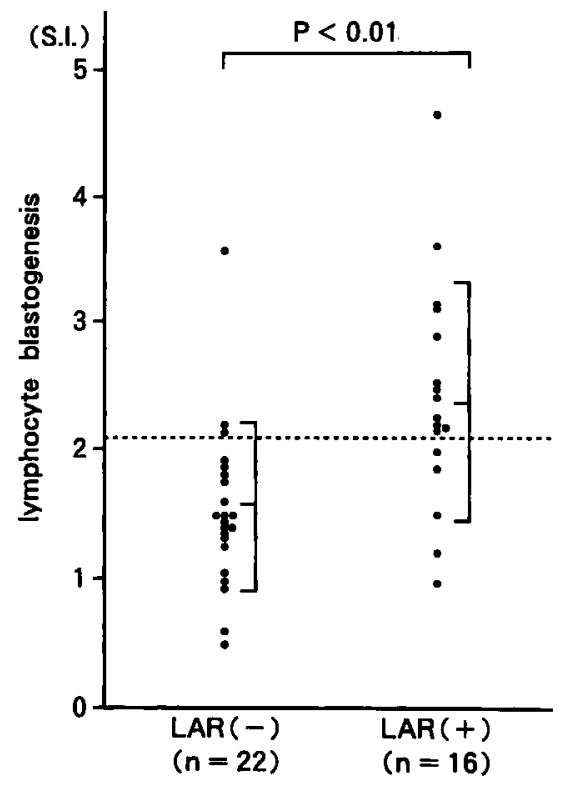

Fig 2 Relation between mite specific Ly-BL and LAR provoked by inhalation of house dust antigen. Mite specific Ly-BL are expressed as S. I.

Ly-BL : lymphocyte blastogenesis LAR: late asthmatic response 


\begin{tabular}{c|cc} 
& \multicolumn{2}{|c}{ LAR } \\
\cline { 2 - 3 } & + & - \\
\hline $\begin{array}{c}\text { Ly-BL } \\
\text { positive } \\
n=18\end{array}$ & $\begin{array}{c}14 \\
(78 \%)\end{array}$ & $\begin{array}{c}4 \\
(22 \%)\end{array}$ \\
\hline $\begin{array}{c}* * \text { negative } \\
n=20\end{array}$ & $\begin{array}{c}8 \\
(39 \%)\end{array}$ & $\begin{array}{c}12 \\
(61 \%)\end{array}$ \\
\hline $\begin{array}{r}* \text { positive S.I. } 33.0 \\
* * \text { negative S.I. }<3.0\end{array}$
\end{tabular}

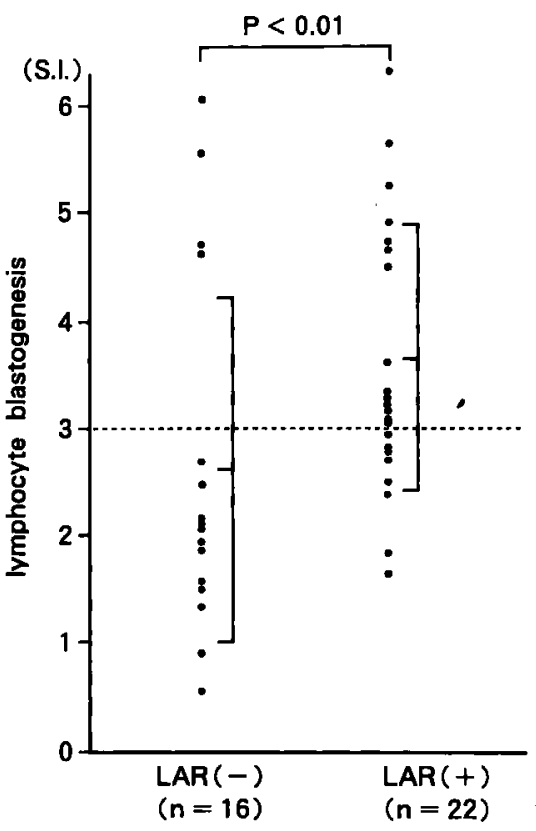

Fig 3 Relation between Candida specific Ly-BL and LAR provoked by inhalation of Candida antigen. Candida specific Ly-BL are expressed by S. I. Ly-BL : lymphocyte blastogenesis LAR: late asthmatic response

た Ly-BL の元進しているB群，C群では LAR の発現は Dual も含めると著明に高率 $(64 \%$, 74\%)であった（Fig. 4).

\section{4. 新分類と臨床所見の関連}

次に各群の臨床的特徴を検討したところまず 現年㱓の比較ではA 群は40歳未満の症例が比較 的多く、B群, C 群, $\mathrm{D}$ 群では40歳以上の症例 が多い傾向が認められた（Fig. 5)。また各群 の発症年龉についてはA群には 40 歳未満の若年 発症例が比較的多く、B群, $\mathrm{C}$ 群, $\mathrm{D}$ 群には40 歳以上の中高年発症例が多い傾向が認められた

(Fig. 6).

次に重症度別の比較ではA 群, B群は軽中等 症例が多く, C群, D群は重症例が多い傾向が 認められた（Fig. 7).

\section{考察}

近年気管支喘息の概念は大きく変化し，特に 成人喘息では炎症細胞による慢性アレルギー性 疾患 ${ }^{1)}$ とてとらえられているが, その病型分類 は喘息がI型アレルギー反応に基づく気道卛縮 性疾患として捉えられていた頃のものがいまだ
Table 1 Asthma classification by mite (M) or Candida (Ca) specific IgE RAST and Ly-BL

Ly-BL : lymphocyte blastogenesis

\begin{tabular}{lcc}
\hline & IgE RAST & Ly-BL \\
\hline A group & + & - \\
B group & + & + \\
C group & - & + \\
D group & - & - \\
\hline
\end{tabular}

IgE RAST : positive score $\geqq 2$ negative score $<2$

M-Ly-BL : positive S. I. $\geqq 2.1$ Ca-Ly-BL : positive S. I. $\geqq 3.0$

用いられており，その分類法では必ずしも近年 の病態概念を表しているとは考え難い。そこで 今回, HD - mite と Candida の様な代表的な 抗原により惹起される気道反応に基づく夫々特 異的な喘息病態に対して検討を加えたところ， IAR と IgE RAST, LAR と Ly-BL に強い相 関のあることが判明した.そこで抗原特異的 IgE 抗体と Ly.BL の S. I. の 2 指標を組み合わせて 


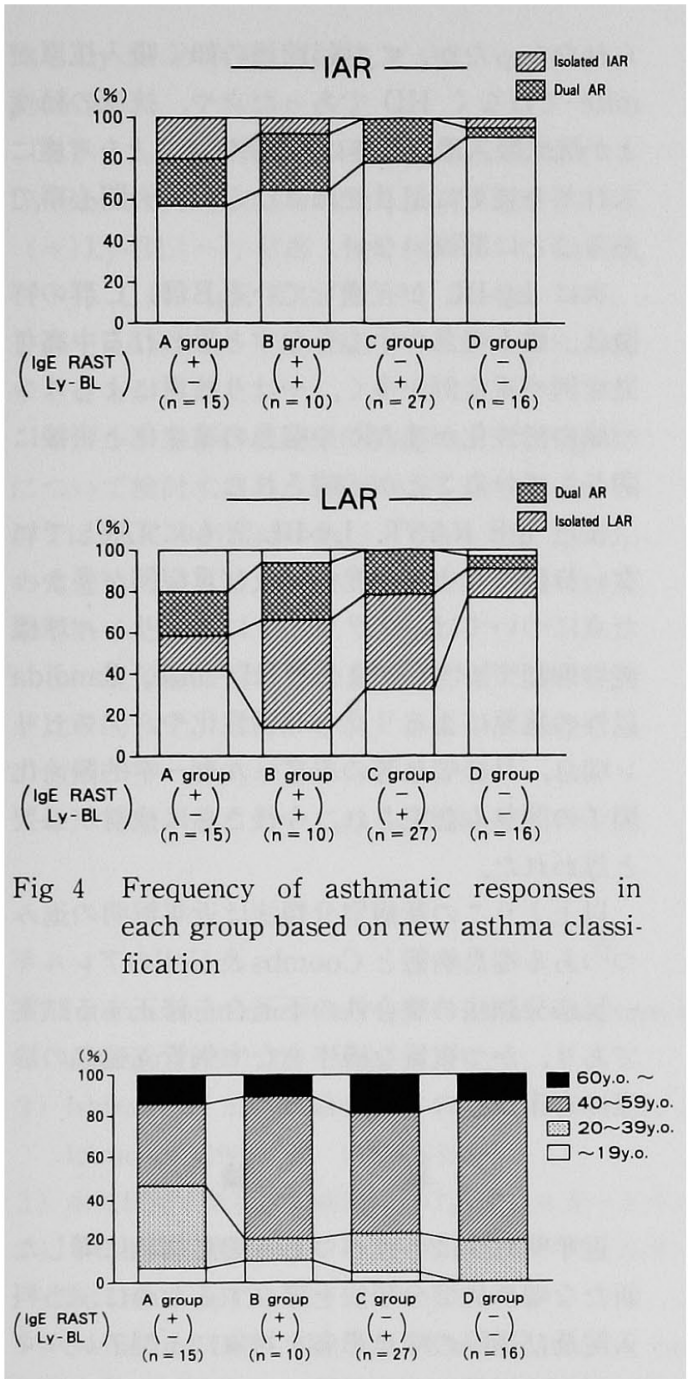

Fig 5 Frequency of patient's age in each group based on new asthma classification

4 群に分類したところ，IgE RAST 陽性のA， B群はIARの出現は半数以下であったが, Ly-BL の六進している B，C群では LARの出現は高 率であった。 また IgE RAST のみ陽性のA群 は若年発症例，その他の群は中高年発症例が多 くを占めており，IgE RAST 陽性の群は軽・中 等症例, 陰性の群は重症例が多く, 特に Ly-BL 克進例でその傾向が顕著であった. 従ってA群 にはIAR を基盤とした軽・中等症の若年アトピ 一型喘息が属し，B群には $\mathrm{A}, \mathrm{C}$ 两群の特徴を 持ち合わせ比較的重症度の高い中高年のアトピ 一型喘息が，C群には LAR や DeAR を基盤

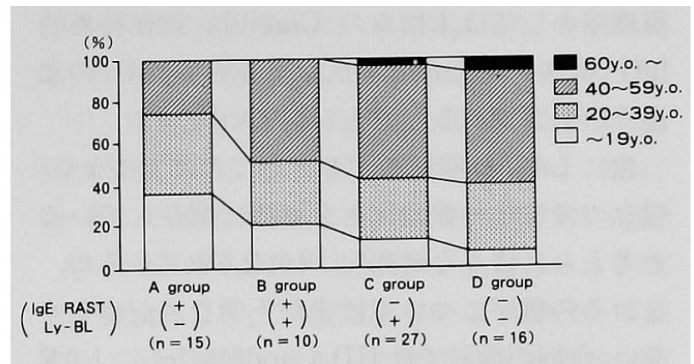

Fig 6 Frequency of patient's onset age in each group based on new asthma classification

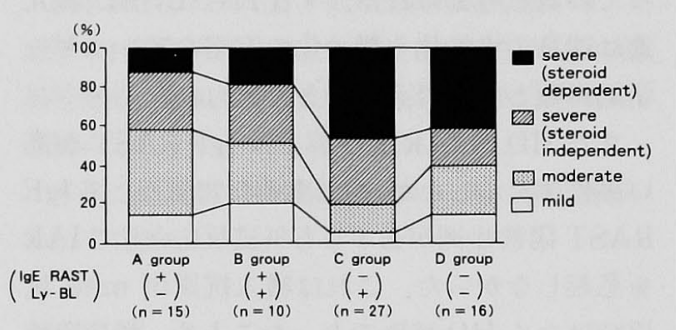

Fig 7 Frequency of asthma severity in each group based on new asthma classification

とした中高年発症型難治性喘息が中心をなす非 アトピー型喘息が，D群には $\mathrm{HD} \cdot$ mite や Candida 抗原に对するいずれの反応も認められ ない重症の喘息が属するものと考之られた。

従来気管支喘息は抗原と肥満細胞・好塩基球 系が $\operatorname{IgE}$ 抗体を介して起こすI 型アレルギ一反 応に基づく疾患として理解されてきた。しかし 成人喘息においては I 型アレルギー反応の関与 が少ない症例も多く，近年III型やI 型アレルギ 一反応の関与 ${ }^{13) 14)}$ も考之られており，木村は成人 喘息の機序として, 肥満細胞よりもむしろ好酸 球，好中球，好塩基球の椂な effector cell とそ れらを統御するリンパ球が中心をなす “細胞反 応型アレルギー, cell-mediated allergy” ${ }^{23344) の ~}$ 存在を提唱している.

一方抗原の側から見るとI型アレルギー反応 の代表的抗原としては HD· mite が重要である と考えられているのに対し, 細胞反応型アレル ギ一の原因抗原としては Candida が想定されて いる.すなわち BPT では, HD·miteが IAR 主体の反応を惹起するのに対し, Candidaでは LAR やDeAR を誘発する事が多く，かかる発 
現機序としては末梢血の Candida 抗原特異的 IgG ${ }_{1}$ 抗体 ${ }^{15)}$, Candida 抗原特異的 Ly-BL の立 進 ${ }^{16)}$ が重要であると考えられている.

更に LARは喘息モデルとしてだけではなく， 喘息の慢性化や難治化とも密接に関与している と考えられ様々な研究 ${ }^{17)-21) か ゙ な さ れ て い る か ゙, ~}$ なおその機序については未だ不明な点が少なく ない. 今回の検討では HD, Candida ともに LAR 発現群においては Ly-BL が有意に元進してお ク,LARには活性化リンハ球が重要な役割を担 っていると考之られた，すなわち Ly-BL の元 進は喘息の慢性化や難治化の有用なアレルギー 学的指標となり得るものと考之られた.

また HDのIAR 発現群では IgE RAST が高 い陽性率を示したが, 逆に重要な知見として IgE RAST 陽性症例が必ずしも気道反応として IAR を惹起しなかった。これは吸入抗原が mite 抗 原ではなく $\mathrm{HD}$ 抗原であったことや，誘発間値 濃度の差についての検討がなされていなかった こともあり, 今後吸入抗原の精製や吸入濃度等 ${ }^{22)}$ も考慮して確認する必要があると思われた。

以上の如く気管支喘息殊に成人喘息は今や IgE RAST を指標としたI 型アレルギー反応の みでは捉え難いことは明白である。すなわち IgE RAST だけではなく III型あるいはN ギ一学的指標も加えなければ喘息病態を適確に 表現することは困難であろう．かかる観点から みると，現在繁用されている Swinefordのアト ピー型, 感染型, 及びこれらの混合型に分類す る方法や, Rackemann に上る外因型, 内因型 の分類方法は IgE 抗体のみをアレルギ一学的指 標として分類されており，不完全な分類として 近年明らかにされつつある喘息病態に即したも のとは言い難い.そこで今回著者は喘息の 2 大 抗原と考えられる HD・mite 及び Candidaに 対する IgE RAST に加之, アレルギー学的指 標として Ly-BL を加之喘息病型分類を試みた. その結果 IgE RAST のみか陽性のA群の特徵 はIARの反応形態をとることが特徴的と考えら れた. そしてA群の現年齢, 発症年齢の特徴と しては, 若年例, 若年発症例が多く, 重症度か らみると比較的軽症例が多く認められた。しか し今回の検討では半数の症例にしかIARが認め
られなかったが，これは前述の如く吸入抗原が mite ではなくHD であった点や, 抗原の精度 とか抗原吸入濃度 ${ }^{22)}$ 等に問題があることを考慮に 入れて今後更に追及せねばならぬ一大関心事で あることに間違いない。

次に Ly-BL が亢進しているB 群, C 群の特 徵は, 成人喘息の中心をなすと思われる中高年 発症例や重症例が多く，やはり抗原によるリン 八球の活性化が LAR や喘息の重症化と密接に 関与していることが示唆された.

また IgE RAST, Ly-BL ともに元進してい ない $\mathrm{D}$ 群にも中高年発症例及び重症例が多かっ た点については，ステロイドによるリンパ球機 能の抑制 ${ }^{2322425)}$, 真菌など HD・mite, Candida 以外の抗原によるリンバ球活性化や，アスピリ ン喘息, 月経喘息等の非アレルギ一学的難治化 因子の関与も想定され，今後さらに検討が必要 と思われた。

以上よりこの新病型分類法は近年解明の進み つつある喘息病態と Coombs \& Gellのアレルギ 一反応分類法の整合性の不適合を修正する試案 であり，かつ複雑な機序をなす気管支喘息の診 療に有用なものと考えられた。

\section{結論}

近年明らかにされつつある喘息病態に即した 新たな喘息病型分類法を確立するために，当科 入院及じ通院の喘息患者を対象にI 型アレルギ 一反応の指標となる HD・mite 及び Candida に対する IgE RASTに加え，それらによる Ly-BL について，それらの抗原吸入誘発試験で発現す る気道反応との関係を検討した.

1) IgE RAST と IARの関倸については IgE RAST 陽性は19例中 9 例（47\%）にIAR を認 めるに過ぎなかった。また HD・mite 抗原によ る IAR 発現群は非発現群に比し IgE RAST score が有意に高い傾向にあった $(\mathrm{p}<0.01)$.

Candida 抗原では IgE RAST と IAR との間 に相関は認められなかった。

2) Ly-BL と LAR の関係については HD • mite 及び Candida 抗原のLy-BL の立進例では LAR 発現例は 14 例中 11 例 $(79 \%)$ と高い一致率 を認めた. また逆に LAR 発現群は非発現群に 
比し Ly-BL が有意に克進していた（ $\mathrm{p}<0.01$, $\mathrm{p}<0.01$ ).

3）1)，2)の結果に基づき IgE RAST と Ly-BLのS. I. 值により喘息をA群：IgE RAST (+) Ly-BL(-), B 群：IgE RAST(+) Ly-BL $(+) ，$ C 群：IgE RAST (-) Ly-BL (+), D群：RAST (-) Ly-BL (-) の 4 群に分類 することが出来た.

4）かかる各群の臨床的特徵のうち気道反応 について検討すると, IgE RAST 陽性のA，B 群ではIARの出現は半数以下であったが, Ly-BL の立進しているB，C群では LAR の出現は高 率であった。

5）現年齢についてはA群は40歳未満の症例 が比較的多く， B群， C群， D群では40歳以上 の症例が多い傾向が認められた。

6）発症年龄については IgE RAST のみ陽
性のA群は若年発症例，その他の群は中高年発 症例が多かった。

7) 重症度については IgE RAST 陽性群は 軽中等症例が，陰性群は重症例が多く, 特に Ly-BL 六進例においてその傾向が顕著であった。 以上 IgE RAST と Ly-BL を指標とする新病 型分類法により，気管支喘息をより適確に分類 することが可能となり，これは喘息病態の本質 に迫る有用な分類法であると思われた。

稿を終えるにあたり，終始御指導御校閲を睗った 恩師木村郁郎教授に深甚の謝意を表すと共に，直接 御指導戴いた国立療羕所南岡山病院高橋清副院長に 深謝いたします。

本稿の要旨は，第42回日本アレルギー学会総会に おいて発表した。

献

1) International consensus report on the diagnosis and management of asthma, Sheffer AL ed. Clin Exp Allergy (1992) 22, Suppl 1, 1.

2) Ishizaka $\mathrm{K}$ and Ishizaka $\mathrm{T}$ : Identification of $\gamma \mathrm{E}$-antibodies as a carrier of reagenic activity. $\mathrm{J}$ Immunol (1967) 99, 1187-1198.

3）木村郁郎：気管支肺病変におけるアレルギーとリン八球。アレルギア (1990) 19，12-16.

4) 木村郁郎：最近のアレルギー学の展開：アレルギーの理論とその展開, 木村郁郎編, 医薬ジャーナル社, 大 阪 (1991) pp 11-22.

5) Swineford O Jr: Asthma : Classification of causes. A recommended classification and a critical review. J Allergy (1954) 25, 151-167.

6) Rackemann FM : A working classification of asthma. Am J Med (1947) 3, 601-606.

7) Scadding JD : Definition and clinical categories of asthma : in Asthma, Clark TJH and Godfrey S eds, Chapman and Hall, London (1977) pp 1.

8) Rose B, Hogg JC and Macklem P : The pathogenesis of bronchial asthma ; in Imunological Diseases, Samter M ed, Little Brown, Boston (1978) pp 852.

9) Pepys $\mathrm{J}$ and Hutchcroft $\mathrm{BJ}$ : Bronchial provocation tests in etiologic diagnosis and analysis of asthma. Am Rev Respir Dis (1975) 112, 829-859.

10) Thurlbeck WM : Pathology of Asthma in Allergy Principle and Practice. 3rd eds, CV Mosby, St Louis (1988) pp 1008-1017.

11）牧野荘平, 小林節雄, 宮本昭正, 信太隆夫, 高橋昭正, 可部順三郎, 中島重德：気管支喘息及び過钽性肺喏 炎における吸入試験の標準法。アレルギー（1982）31，1074-1076.

12）武田 昌：気管支喘息におけるリンパ球機能に関する研究. 第 1 編 気管支喘息におけるBAL 液中並じに 末梢血中リンバ球の吸入抗原に对する幼若化反応の検討．岡山医誌（1991）103，387-397.

13）宮川秀文：重症難治性喘息におけるIV型アレルギ一反応に関する研究. 第 1 編 カンジタ抗原による末梢血 
及U゙ BALF 中リンパ球の interleukin 2 (IL-2) 産生能の検討. 岡山医誌（1988）100，565-575.

14）宮川秀文：重症難治性喘息における $\mathrm{N}$ 型アレルギー反応に関する研究. 第 2 編 カンジダ抗原による末梢血 単核球由来の好中球遊走活性の検討。岡山医誌（1988）100，577-587。

15）小栗栖和郎, 高橋 清, 多田慎也, 宗田 良, 難波一弘, 高田 鐜, 難波康夫, 金廣有彦, 谷本 安, 木村 五郎，高橋寿保，木村郁郎，谷崎勝朗：成人喘息におけるIgGサブクラス抗体と遲発型気道反応の関連に ついて. アレルギー (1991) 40，506-515.

16）金廣有彦, 高橋 清, 多田慎也, 宗田 良, 猪木篤弘, 谷本 安, 木村五郎, 岡本章一, 岡野智治, 古藤直 紀, 木村郁郎：気管支喘息の遲発型気道反応におけるリンバ球の関与について.アレルギー (1992) 41, 739 -748 .

17) deMonchy JGR and Kaufman HF, Venge P, Koeter GH, Sluiter HJ, Jansen HM and DeVries K : Bronchoalveolar eosinophilia during allergen-induced late asthmatic reaction. Am Rev Respir Dis (1985) 131, 373-376.

18) Gwynn CM, Ingram J, Almousawi $T$ and Stanworth $D R:$ Bronchial provocation tests in atopic patients with allergen-specific $\mathrm{IgG}_{4}$ antibodies. Lancet (1982) 1, 254-256.

19) Behrens BL, Marsh WR, Henson PM and Larsen GL : Passive transfer of the late pulmonary response in an animal model. Relationship of immunologic status to pulmonary physiologic changes. Am Rev Respir Dis (1983) 127, 65.

20) Metzger WJ, Wassermann SI, Richerson HB and Donnelly A : Evidence for release of eosinophil and neutrophil chemotactic factors during early and late asthmatic responses. Clin Res (1983) 31, $165 \mathrm{~A}$.

21) Kaliner $M$ : Hypothesis on the contribution of late-phase allergic responses to the understanding and treatment of allergic diseases. J Allergy Clin Immunol (1984) 73, 311-315.

22) Ihre E, Axelsson IG and Zetterström $O$ : Late asthmatic reactions and bronchial variability after challenge with low doses of allergen. Clin Allergy (1988) 18, 557-567.

23) Wyllie $\mathrm{AH}$, Poznansky $\mathrm{MC}$ and Gordon $\mathrm{ACH}$ : Glucocorticoid resistant asthma : evidence for a defect in mononuclear cells ; in Asthma clinical pharmacology and therapeutic progress, Kay AB eds, Blackwell Scientiffic Publications, Oxford (1986) pp 306-314.

24) Corrigan CJ, Brown PH, Barnes NC, Szefler SJ, Tsai J-J, Frew A J and Kay AB : Glucocorticoid pharmacokinetics, glucocorticoid receptor characteristics, and inhibition of peripheral blood $\mathrm{T}$ cell proliferation by glucocorticoid in vitro. Am Rev Respir Dis (1991) 144, 1016-1025.

25) Alvarez A, Surs W, Leung DYM. Iklê D, Gelfand EW and Szefler SJ : Steroid-resistant asthma : Immunologic and pharmacologic features. J Allergy Clin Immunol (1992) 89, 714-721. 
A new asthma classification based on its pathophysiology using $\operatorname{IgE}$ antibody (RAST) and lymphocyte activation as parameters Kazuhi KIMURA

Second Deparrment of Internal Medicine, Okayama University Medical School, Okayama 700, Japan

(Director : Prof. I. Kimura)

To establish a new classification in bronchial asthma, antigen-induced immediate asthmatic response (IAR) and late asthmatic response (LAR) to mite and Candida were compared with antigen specific IgE antibody (IgE RAST) and lymphocyte blastogenesis (Ly-BL) in asthmatics.

Half of asthmatics with a high score on mite IgE RAST could not be provoked to IAR, although almost all of patients with house dust-induced IAR showed a high score on mite IgE RAST.

However, asthmatics with enhanced Ly-BL following exposure to mite and Candida showed highly provoked LAR by antigen inhalation, and LAR patients showed significantly enhanced Ly-BL by both antigens $(\mathbf{p}<0.01)$.

Bronchial asthmatics were classified into the following 4 groups using those parameters ; $A$ group (IgE RAST + , Ly-BL-), B group (IgE RAST +, Ly-BL+), C group (IgE RAST-, Ly-BL+), D group (IgE RAST-, Ly-BL-). Half of the patients with IAR belonged to the $A$ and $B$ groups, and almost all of the LAR patients were in the $B$ or $C$ group. Patients in the A group predominantly showed early onset, however patients in the $B$ and $C$ groups showed late onset. $A$ and $B$ group patients were mild or moderate asthmatics, but severe asthmatics belonged to the $\mathrm{C}$ and $\mathrm{D}$ groups.

These data suggest that the C group showed only Ly-BL led LAR by "cell-mediated allergy" in late onset severe asthma. 